\title{
Corpus callosum structural characteristics in very preterm children and adolescents: developmental trajectory and relationship to cognitive functioning
}

\author{
Vanessa Siffredi ${ }^{123}$, PhD, Maria Chiara Liverani1 ${ }^{14}$, PhD, Cristina Borradori Tolsa ${ }^{1}$, MD, Russia Hà-Vinh \\ Leuchter $^{1^{*}}$, MD, Petra Susan Hüppi ${ }^{1 *}$, MD, \\ ${ }^{1}$ Division of Development and Growth, Department of Paediatrics, Gynaecology and Obstetrics, \\ Geneva University Hospitals, Geneva, Switzerland \\ ${ }^{2}$ Institute of Bioengineering, Center for Neuroprosthetics, Ecole Polytechnique Fédérale de \\ Lausanne, Switzerland \\ ${ }^{3}$ Department of Radiology and Medical Informatics, Faculty of Medicine, University of Geneva, \\ Switzerland \\ ${ }^{4}$ SensoriMotor, Affective and Social Development Laboratory, Faculty of Psychology and Educational \\ Sciences, University of Geneva, Geneva, Switzerland \\ * These authors contributed equally to this work
}

\section{Address correspondence to:}

Vanessa Siffredi

Child Development Lab \& Medical Image Processing Lab - Campus Biotech, Chemin des Mines 9, 1202 Genève

email: vanessa.siffredi@unige.ch

\begin{abstract}
The corpus callosum is the largest white matter commissural pathway, important for interhemispheric communication. Previous studies suggest that structural alteration of the corpus callosum occurs after a preterm birth in the neonatal period that lasts across childhood, adolescence and young adulthood. The present study aims to unravel corpus callosum structural characteristics across development in very preterm children and adolescents aged 6 to 15 years, as well their associations with general intellectual, executive and social functioning. Neuropsychological assessments of general intellectual, executive and social functioning as well as T1-weighted and multi-shell diffusion MRI were collected in 79 very preterm and 46 full term controls aged 6 to 15 years. Volumetric, diffusion tensor imaging (DTI) and neurite orientation dispersion and density imaging (NODDI) measures were extracted on 7 portions of the corpus callosum using TractSeg. A multivariate data-driven approach (partial least squares correlation) and an age normative modelling approach were used to explore associations between callosal characteristics and neuropsychological outcomes. The very preterm and full-term control group showed similar trends of white-matter maturation over time, i.e., increase FA and reduced ODI, in all segments of the corpus callosum, that was associated with increase in general intellectual functioning. However, using age-related normative modelling of volumetric, tensor and NODDI diffusion measures, findings show atypical pattern of callosal development in the very preterm group with reduced callosal maturation over time. Atypical developmental trajectory of callosal maturation was associated with poorer general intellectual and working memory functioning as well as with greater prematurity. The present study also illustrates how normative age modelling approach allows to shed new insight into neurodevelopmental trajectory in the VPT population and its association with functional outcomes.

NOTE: This preprint reports new research that has not been certified by peer review and should not be used to guide clinical practice.
\end{abstract}


medRxiv preprint doi: https://doi.org/10.1101/2021.11.02.21265740; this version posted November 8, 2021. The copyright holder for this preprint (which was not certified by peer review) is the author/funder, who has granted medRxiv a license to display the preprint in

All rights reserved. No reuse allowed without permission.

\section{Introduction}

With more than 190 million axon fibres, the corpus callosum is a major white matter commissural pathway that connects neurons between the two cerebral hemispheres of the human brain (1). The corpus callosum (CC) plays a crucial role for interhemispheric communication of low-level sensory and motor information but also for higher-level cognitive information (2-4). As a consequence, structural alteration of the corpus callosum have been associated with reduced general intellectual (5-8), executive (9-13) and social functions (14-18). In typical foetal development, the basic structure and shape of the corpus callosum is completed by 20 gestational weeks (1, 19, 20). However, it continues to increase in size over the third trimester of pregnancy and postnatally up until 2 years of age when it reaches a size comparable to adults (21-24). This developmental period is accompanied by axon growth followed by a period of synaptic pruning $(25,26)$. Thus, very preterm (VPT) birth, i.e., before 32 completed weeks of gestation, occurs during a highly sensitive period of callosal development.

In VPT individuals, previous studies indeed showed structural alteration of the corpus callosum in the neonatal period (27-32) that lasts across childhood, adolescence and young adulthood. Firstly, reduction in callosal volume in VPT have been found at different ages across childhood from 7-yearold (33), adolescence and young adulthood up until 20 years of age (34-38). Volumetric alteration was found more specifically in the posterior area of the corpus callosum and reduction in callosal volume was correlated with increased prematurity, and (34-37). Using longitudinal data, Allin and colleagues (2007) showed increase volumetric growth in a large sample of 15 to 19-year-old preterm individuals compared to full-term controls (39). However, despite this accelerated growth, CC volume seem to stay reduced in this population. Secondly, structural alteration of the corpus callosum have been explored using diffusion-weighted imaging and the diffusion tensor model (DTI) known to provides insight into the microstructure and connectivity of white matter tracts (40). Reduction in callosal fractional anisotropy (FA) values, a measure of the directionality of diffusion, were found at early ages in VPT children $(41,42)$ as well as in young adolescents $(43)$, especially in posterior CC portions. Mean diffusivity (MD), a measure of overall diffusion(with a larger MD associated with reduced integrity of the white-matter (29)), was found to be increased in VPT children (41) and young adults (44). Importantly and in line with the implication of the corpus callosum in neurodevelopment, these volumetric and microstructural callosal alterations in VPT individuals have been consistently associated with poorer cognitive functioning, including general intellectual and executive outcomes $(33,35-37,44)$. 
medRxiv preprint doi: https://doi.org/10.1101/2021.11.02.21265740; this version posted November 8, 2021. The copyright holder for this preprint (which was not certified by peer review) is the author/funder, who has granted medRxiv a license to display the preprint in

All rights reserved. No reuse allowed without permission.

While DTI and its indices of FA and MD are commonly used to study white matter microstructural properties, they lack specificity on informing on the underlying biological mechanisms. As an illustration, a reduction of FA in a white matter tract can be driven by multiple contributing factors such as decreased myelination or decreased axonal fibre density (45). Furthermore, lower FA will be evaluated in voxels containing crossing fibres compared to those without crossing fibres, a finding which might incorrectly be interpreted as reduced structural integrity (46). In this context, multi-shell diffusion imaging combined with the application of advanced statistical models provides an opportunity to measure more specific information regarding white matter microstructural properties. One such model is the neurite orientation dispersion and density imaging (NODDI; (47)) that captures neurite (dendrites and axons) morphology, providing parameters including neurite density index (NDI) and orientation density index (ODI). More specifically, while NDI represents the intra-cellular volume fraction, estimating the density of axons within a voxel, ODI represents the angular variation of neurite orientations, reflecting the bending and fanning of axons (47).

Building on previous findings and using advanced methodology, this study aimed to examine corpus callosum structural development in VPT children and adolescents aged 6 to 15 years using a comprehensive set of structural and microstructural measures and its association with general intellectual, executive and social functioning. Firstly, pattern of associations between callosal volumetric, tensor and NODDI measures, and age, gestational age and neuropsychological functioning were explored in full-term and VPT individuals. Secondly, we employed an age-related normative modelling approach on callosal volumetric, tensor and NODDI measures. This approach consists of fitting a mathematical distribution that finds the relationship between age and a given callosal structural characteristic measure, as well as the variation in this relationship expected in a group of full-term controls (48-50). Callosal structural characteristic measures of VPT individuals can then be understood in relation to this normative model and allows identification of deviations from normative callosal development for each individual. In the VPT group, we then used this approach to explore specific association between deviation from normative corpus callosum structural development with age, gestational age, neuropsychological functioning.

In summary, association between corpus callosum structural development using volumetric, tensor and NODDI measures and age, gestational age and neuropsychological functioning were explored in full-term and VPT individuals using both a traditional and a normative modelling approaches. This procedure allowed us to better understand how callosal structural development is influenced by age 
medRxiv preprint doi: https://doi.org/10.1101/2021.11.02.21265740; this version posted November 8, 2021. The copyright holder for this preprint (which was not certified by peer review) is the author/funder, who has granted medRxiv a license to display the preprint in

All rights reserved. No reuse allowed without permission.

and gestational age factors as well as its association with general intellectual, executive and social functioning.

\section{Methods}

\section{Participants}

Participants of the current study were recruited for two intervention studies ('Mindful preterm teens' study (51); and 'Vis-à-Vis' study), between January 2017 and July 2019. 392 VPT children and adolescents born < 32 gestational weeks between 01.01.2003 and 31.12.2012, in the Neonatal Unit at the Geneva University Hospital (Switzerland) and followed up at the Division of Child Development and Growth, were invited to participate. VPT children and adolescents were excluded if they had an intelligence quotient below 70, sensory or physical disabilities (cerebral palsy, blindness, hearing loss), or an insufficient understanding of French. A total of 108 VPT participants were enrolled. Of the 108 participants enrolled, 79 completed both the brain MRI scan and neuropsychological assessment. A total of 65 were included in the current study (diffusion sequences not completed: $n=9$; high level of motion artefacts: $n=5)$. Moreover, 46 term-born children and adolescents aged between 6 and 14 years old were recruited through the community. Of the 46 participants, 41 completed both the brain MRI scan and neuropsychological assessment. A total of 39 were included in the current study (diffusion sequences not completed: $n=2$ ).

This study was approved by the Swiss Ethics Committees on research involving humans, ID: 201500175. Written informed consent was obtained from the principal caregiver and from the participant.

\section{Neuropsychological measures}

Participants' general intellectual, executive and social functioning were assessed using neuropsychological testing and computerised neurocognitive tasks, for detailed information see Supplementary Table S1.

\section{(i) General intelligence measure}

In participants from 6-year-old to 9 years and 11-month-old, the Kaufman Assessment Battery for Children - 2nd Edition (K-ABC-II; (52) was used to evaluate the Fluid-Crystallized Index (FCI) as a measure of general intellectual functioning. The $\mathrm{FCl}$ is derived from a linear combination of 10 core subtests that composed fiver first-order scale scores (i.e., Short-Term memory, Long-Term Storage 
medRxiv preprint doi: https://doi.org/10.1101/2021.11.02.21265740; this version posted November 8, 2021. The copyright holder for this preprint (which was not certified by peer review) is the author/funder, who has granted medRxiv a license to display the preprint in

All rights reserved. No reuse allowed without permission.

and Retrieval, Visual Processing, Fluid Reasoning, and Crystallized Ability). For children younger than 7 year of age, different subset combination is administer to calculate the FCl. In participants from 10 to 14 years of age, the Wechsler Intelligence Scale for Children - 4th Edition (WISC-IV; (53) was used to evaluate the General ability index (GAl) as a measure of general intellectual functioning. The GAl is derived from the core verbal comprehension and perceptual reasoning subtests. Both of these measures of general intellectual functioning, $\mathrm{FCl}$ and $\mathrm{GAl}$, have a mean of 100 and a standard deviation of 15.

(ii) Executive functioning measures

Executive functioning was assessed based on the model of Anderson (54) using: a) the LetterNumber Sequencing subtest from Wechsler Intelligence Scale for Children, $4^{\text {th }}$ Edition (WISC-IV) assessing working memory, which belongs to the cognitive flexibility subdomain (54); and b) a computerised Flanker Visual Filtering Task, in which reaction time of the congruent condition was used to assess speed of processing, which belongs to the information processing subdomain; and the inhibition score (accuracy in incongruent conditions - accuracy in congruent conditions) was used as a measure of the attentional control subdomain $(54,55)$.

Given age-related increase in executive functioning, raw scores were regressed on age at testing; the standardised residuals for the three executive measures were retained for following analysis, called working memory, processing speed and inhibition scores.

(iii) Social functioning measures

Social functioning was assessed using subtests of the Developmental Neuropsychological Assessment - 2nd Edition (NEPSY-II; (56) including : a) the Affect Recognition subtest giving a total score assessing facial emotional recognition; and b) the Theory of Mind subtest giving a total score measuring the ability to understand mental functions, such as belief, intention or deception.

Given age-related increase in social functioning, raw scores were regressed on age at testing; the standardised residuals for the two social measures were retained for following analysis, called affect recognition and theory of mind scores.

\section{Magnetic resonance imaging}

\section{Magnetic Resonance Imaging acquisition}

MRI data were acquired at the Campus Biotech in Geneva, Switzerland, using a Siemens 3T Magnetom Prisma scanner. All participants completed a simulated "mock" MRI session prior to their MRI scan. This preparation process was conducted by trained research staff and allowed 
medRxiv preprint doi: https://doi.org/10.1101/2021.11.02.21265740; this version posted November 8, 2021. The copyright holder for this preprint (which was not certified by peer review) is the author/funder, who has granted medRxiv a license to display the preprint in

All rights reserved. No reuse allowed without permission.

participants to familiarise themselves with the scanner and the scanning process, eventually raising any concerns they might have had prior to the MRI scan. Furthermore, this process is known to facilitated acquisition of good quality MRI images in children and adolescents $(57,58)$. Structural T1weighted MP-RAGE (magnetization-prepared rapid gradient-echo) sequences was acquired using the following parameters: voxel size $=0.9 \times 0.9 \times 0.9 \mathrm{~mm}$; repetition time $(\mathrm{TR})=2,300 \mathrm{~ms}$; echo time $(T E)=2.32 \mathrm{~ms}$; inversion time $(T I)=900 \mathrm{~ms}$; flip angle $(F A)=8^{\circ}$; and field of view $($ Fov $)=240 \mathrm{~mm}$. A multi-shell diffusion-weighted (DW) echo planar imaging (EPI) protocol was used and included four shells. The first sequence, referred to as 'b200', was acquired with b-values of $200 \mathrm{~s} / \mathrm{mm} 2,10$ gradient directions, $4 \mathrm{~b}$-value $=0 \mathrm{~s} / \mathrm{mm} 2$ images, $\mathrm{TR}=7000 \mathrm{~ms}, \mathrm{TE}=87 \mathrm{~ms}$, $\mathrm{FOV}=234 \times 243 \mathrm{~mm}$, slice thickness $=1.3 \mathrm{~mm}$, voxel size $=1.3 \times 1.3 \times 1.3 \mathrm{~mm}$. The second sequence, referred to as 'b1700', was acquired with b-values of $1700 \mathrm{~s} / \mathrm{mm} 2,30$ gradient directions, $4 \mathrm{~b}$-value $=0 \mathrm{~s} / \mathrm{mm} 2$ images, TR $=7000 \mathrm{~ms}, \mathrm{TE}=87 \mathrm{~ms}, \mathrm{FOV}=234 \times 243 \mathrm{~mm}$, slice thickness $=1.3 \mathrm{~mm}$, voxel size $=1.3 \times 1.3 \times 1.3 \mathrm{~mm}$. The third sequence, referred to as 'b4200a', was acquired with b-values of $4200 \mathrm{~s} / \mathrm{mm} 2,26$ gradient directions, 4 b-value $=0 \mathrm{~s} / \mathrm{mm} 2$ images, $\mathrm{TR}=7000 \mathrm{~ms}, \mathrm{TE}=87 \mathrm{~ms}, \mathrm{FOV}=234 \times 243 \mathrm{~mm}$, slice thickness $=1.3 \mathrm{~mm}$, voxel size $=1.3 \times 1.3 \times 1.3 \mathrm{~mm}$. The forth sequence, referred to as 'b4200b', was acquired with b-values of $4200 \mathrm{~s} / \mathrm{mm} 2,24$ gradient directions, $4 \mathrm{~b}$-value $=0 \mathrm{~s} / \mathrm{mm} 2$ images, TR $=7000 \mathrm{~ms}$, TE = $87 \mathrm{~ms}, \mathrm{FOV}=234 \times 243 \mathrm{~mm}$, slice thickness $=1.3 \mathrm{~mm}$, voxel size $=1.3 \times 1.3 \times 1.3 \mathrm{~mm}$.

\section{Volumetry}

Volumetric measurements of the corpus callosum were based on T1-weighted MP-RAGE images and obtained using Freesurfer 5.3.0 and the recon-all function. The corpus callosum was divided into five neuroanatomically based partitions (59). Visual quality control of the original T1 image and of the corpus callosum segmentations was completed for all participants.

\section{Diffusion image preprocessing and models fitting}

A flowchart summarizes diffusion image preprocessing, models fitting tractography and tractometry measures, see Figure 1.

Visual inspection of raw data for brain coverage, spike artefacts, severe head motion, and other severe image artefacts was completed and participants were excluded if necessary. The four diffusion shells (b200, b1700, b4200a, b4200b) were preprocessed independently using MRtrix3 (60) and using the following pipeline: a) denoising (61-63), b) Gibbs ringing removal (64), c) correction for movement and eddy current-induced geometric distortions using the eddy tool implemented in FSL (65). The first $b=0 \mathrm{~s} / \mathrm{mm} 2$ images of the b1700, b4200a, b4200b sequences were linearly 
medRxiv preprint doi: https://doi.org/10.1101/2021.11.02.21265740; this version posted November 8, 2021. The copyright holder for this preprint (which was not certified by peer review) is the author/funder, who has granted medRxiv a license to display the preprint in All rights reserved. No reuse allowed without permission.

registered to the first $\mathrm{b}=0 \mathrm{~s} / \mathrm{mm} 2$ image of the b200 sequence using FreeSurfer to bring them into b200 space before merging them together. The brain extraction tool (BET) from FSL (66) was then applied to the combined b200, b1700, b4200a, b4200b image to remove non-brain tissue and subsequently intensity normalisation was applied. Following Pines and colleague's (2020) recommendations (67), the resulting multi-shell diffusion weighted image was then used for models fitting, including the Diffusion Tensor Imaging (DTI) model and the Neurite Orientation Dispersion and Density Imaging (NODDI).

The DTI model was applied to the resulting multi-shell diffusion weighted image and whole-brain maps of fractional anisotropy (FA) and mean diffusivity (MD) were calculated for each participant. FA (between 0 and 1) is a measure of the directionality of diffusion that characterise the variance of the three eigenvalues pairs that represent the direction and magnitude of diffusivity along the three orthogonal axes $(\mathrm{v} 1, \lambda 1 ; \mathrm{v} 2, \lambda 2 ; \mathrm{v} 3, \lambda 3) . \mathrm{MD}$ is the mean of the 3 eigenvalues and represents the average magnitude of diffusion (57). In addition, the NODDI Matlab Toolbox was used to extract maps of neurite density index (NDI) and fibre orientation dispersion (ODI) across the brain for each participant, http://www.nitrc.org/projects/noddi_toolbox. NDI and ODI were estimated from the resulting multi-shell diffusion weighted image using the NODDI model (47). ODI characterises the angular variation and spatial configuration of neurite structures. NDI represents the fraction of tissue that comprises axons or dendrites (also referred to as intra-neurite volume fraction).

\section{Tractography and tractometry measures}

Whole-brain fibre orientation distributions (FOD) were estimated using with the multi-shell multi-tissue constrained spherical deconvolution (MSMT-CSD) method (68), resulting in a condensed representation of diffusion along three principal fibre directions per voxel according to tissue type (grey, white, cortico-spinal fluid). Tractography-based Segmentation (TractSeg) uses a supervisedlearning approach with a convolutional neural network-based that directly segments tracts in the field of fibre orientation distribution function (fODF) peaks without using parcellation (69). TractSeg has achieved state-of-the-art performance and allows for an accurate reconstruction of fibre tracts in participant space, thus avoiding the problem of inaccurate coregistration of tracts with varying size and shape. Whole-brain fibre orientation distribution function (fODF) peaks map were input into a two stage fully convolutional neural network trained using segmented priors of 72 anatomically welldefined white matter tracts from the Human Connectome Project. The 7 segments of the corpus callosum were defined as tracts of interest. Using the tractometry function, along-tract mean FA, $\mathrm{MD}, \mathrm{NDI}$ and $\mathrm{ODI}$ were calculated for the 7 white-matter segments of the corpus-callosum (70). 


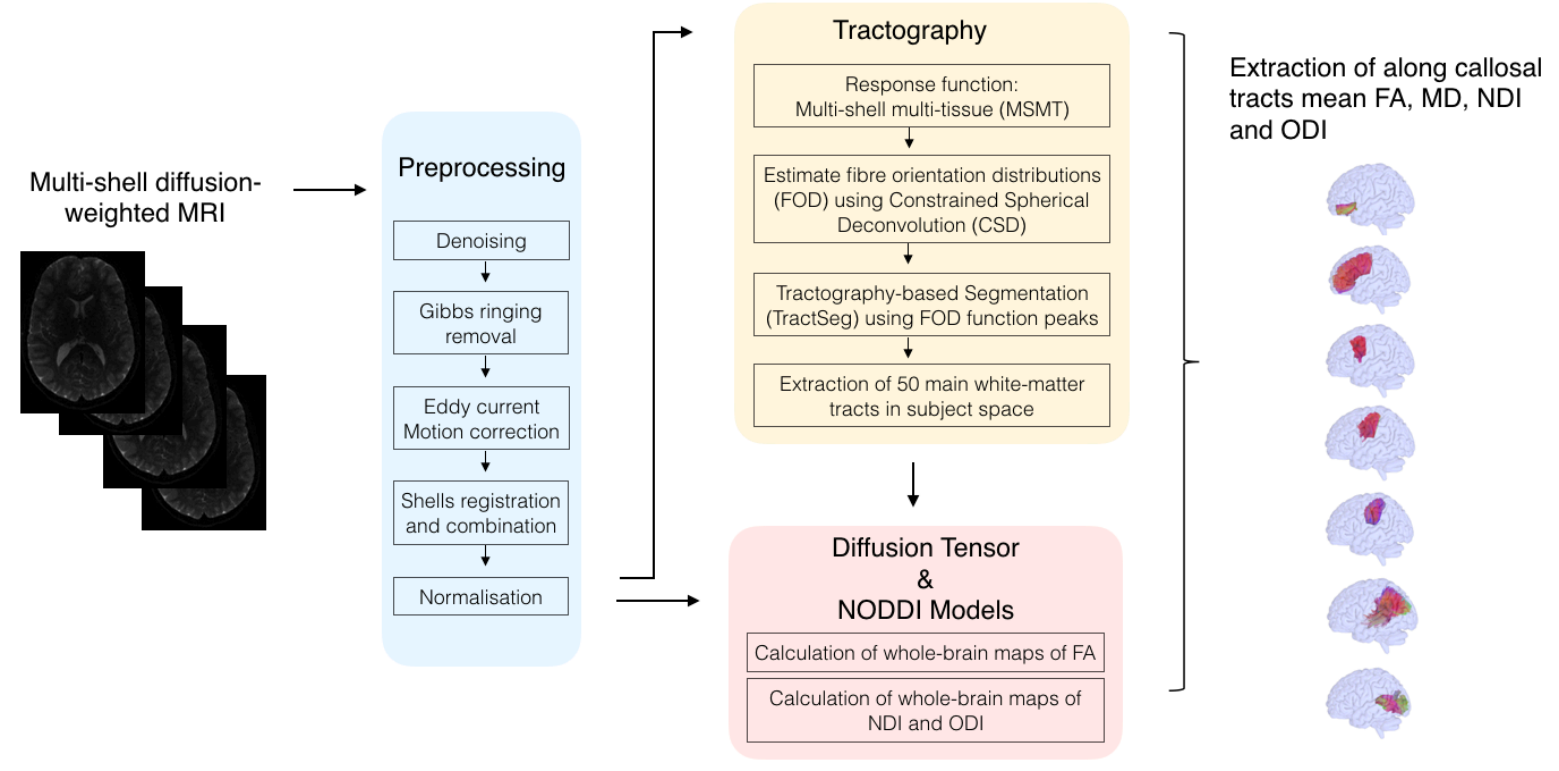

Figure 1. Flowchart summarizing diffusion image preprocessing, models fitting, tractography and tractometry measures. FA, Fractional Anisotropy; MD, Mean Diffusivity; NDI, Neurite Density Index; ODI, Orientation Dispersion Index

\section{Normative Age Modelling}

Age-related normative modelling was completed for all measures of corpus-callosum structural characteristics including: 5 volumetric measures, 7 along-tract corpus callosum mean FA measures, 7 along-tract corpus callosum mean MD measures, 7 mean NDI measures, 7 mean ODI measures. Age-related normative modelling was done utilising participants from the full-term control group performed using R version 4.0.3 (71) and RStudio version 1.3.1093 (72) and using the methods recently described by Bethlehem and colleagues (2020). A LOESS Curve (Local Polynomial Regression) was fitted on the corpus callosum structural characteristic measures of the full-term control group. LOESS is a nonparametric method that uses local weighted regression to fit a smooth curve through points in a scatter plot. The local width of the regression (smoothing kernel) was determined by the model using the R optim function from the stats package in which the overall smallest sum of squared errors used hyperparameter optimisation from 5\% until 100\% of the full age range using Brent's method (73). This approach allows to fit potentially nonlinear relationship between age and corpus callosum structural characteristics. In the current study, age ranges from 72 to 173 months, equivalent to 6 to 14-year-old and 5 months. As a trade-off between adequate representation of developmental trajectories of corpus callosum structural characteristics and ensuring large enough subsets of full-term individuals, four age bins of 25.5 months each were created to align the full-term and the VPT groups (i.e., 72 to 96.5 months; 96.6 to 122 months; 
medRxiv preprint doi: https://doi.org/10.1101/2021.11.02.21265740; this version posted November 8, 2021. The copyright holder for this preprint (which was not certified by peer review) is the author/funder, who has granted medRxiv a license to display the preprint in

All rights reserved. No reuse allowed without permission.

122.1 to 148 months; 148.1 to 173 months), see Supplementary Table S2. For each age bin and every corpus callosum structural characteristics, a normative mean and standard deviation from the full-term group was calculated. These statistical norms were then used to compute a W-score (analogous to a z-score) for every VPT participants and every corpus callosum structural characteristics:

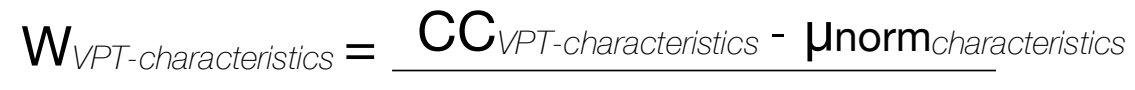

\section{Onorm characteristics}

The W-score for a VPT participant quantified deviation from normative neurodevelopment for a given measure of corpus callosum structural characteristic. As W-scores are computed for every corpus callosum structural characteristics, we get a W-score for each VPT participant showing how each corpus callosum structural characteristics for that individual is atypical relative to full-term norms. See Figure 2 for a schematic overview of the age-related normative modelling procedure used here and based on Bethlehem and colleagues (2020).
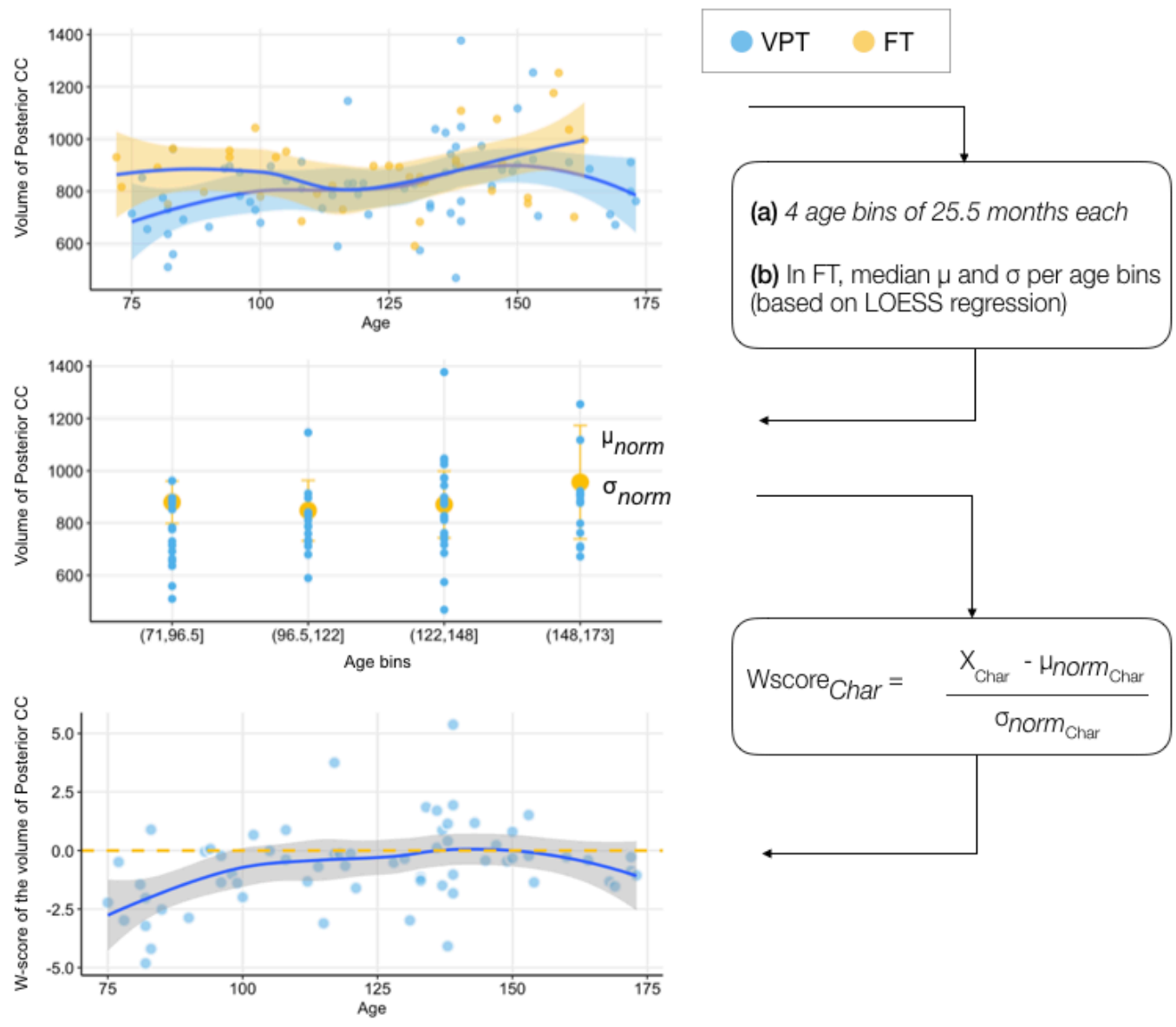
medRxiv preprint doi: https://doi.org/10.1101/2021.11.02.21265740; this version posted November 8, 2021. The copyright holder for this preprint (which was not certified by peer review) is the author/funder, who has granted medRxiv a license to display the preprint in

All rights reserved. No reuse allowed without permission.

Figure 2. Schematic overview of the age-related normative modelling procedure based on Bethlehem and colleagues (2020). Briefly, LOESS regression was used to estimate developmental trajectories in full-term (FT) controls for each callosal measures, i.e., volumetric, tensor and NODDI measures. In the illustration above, volumetric measures of posterior portion of the corpus callosum was used. Age-bins of 25.5 months were created to align the full-term (FT) and very-preterm (VPT) groups. A normative mean and standard deviation from the full-term group was then computed for each age-bin and each callosal characteristic measures. These statistical norms were then used to compute a W-score for every VPT individuals and every callosal structural characteristic measure, called Char. VPT are represented in blue and FT in yellow.

\section{Statistical analyses}

Partial least square correlation analyses (PLSC) were performed to evaluate association between age, gestational age, general intellectual, executive and social functioning measures with corpus callosum structural characteristics. PLSC is a data-driven multivariate technique that maximizes the covariance between two matrices by identifying latent components which are linear combinations of the two matrices, i.e., neurobehavioural measures and corpus callosum structural characteristics measures (74). A publicly available Matlab PLSC implementation was used: https://github.com/danizoeller/myPLS (75, 76). Three PLSC were computed as follow:

- In the full-term control group using corpus callosum structural characteristic measures:

PLSC was used to evaluate association between age, gestational age, general intellectual, executive and social functioning measures with corpus callosum structural characteristics in the full-term control group. Neurobehavioural data refers to: age, gestational age at birth and the 6 neuropsychological measures of general intellectual, executive and social functioning. Neurobehavioural data were stored in a $39 \times 8$ matrix denoted $X$. Each row of $X$ represents one participant and the matrix's 8 columns are made up of age, gestational age at birth and the 6 neuropsychological measures. Corpus callosum structural characteristic measures were gathered in a $39 \times 33$ matrix denoted $Y$, with each row matching one participant and each column one corpus callosum structural characteristic measure. A cross-covariance matrix was then computed between $X$ (participants $X$ neurobehavioural values) and $Y$ (participants $X$ corpus callosum structural values). Singular value decomposition was then applied to this cross-covariance matrix, resulting in latent components. Each latent component is composed of a set of neurobehavioural loadings and corpus callosum structural characteristic loadings, akin to structure coefficients. Structure coefficients lie 
medRxiv preprint doi: https://doi.org/10.1101/2021.11.02.21265740; this version posted November 8, 2021. The copyright holder for this preprint (which was not certified by peer review) is the author/funder, who has granted medRxiv a license to display the preprint in

All rights reserved. No reuse allowed without permission.

between-1 and 1 and can be interpreted similarly to correlation values. Structure coefficients or loadings reflect the direct contribution of a predictor to the predictor criterion independently of other predictors, which can be critical when predictors are highly correlated between each other (i.e., in presence of multicollinearity (77)). Here, loadings indicate how strongly each neurobehavioural measures and corpus callosum structural characteristic measures contribute to the multivariate association of neurobehavioral measures and corpus callosum structural characteristics. The significance of latent components was determined by permutation testing (1000 permutations) and consider robust at $p<0.01$. Stability of neurobehavioural loadings and corpus callosum structural characteristic loadings were estimated using bootstrapping (500 bootstrap samples with replacement). Bootstrapped z-scores for each neurobehavioural measures and corpus callosum structural characteristic measures were calculated by dividing each neurobehavioural and corpus callosum structural characteristics correlation coefficient by its bootstrap-estimated standard deviation, and a p-value was obtained for each bootstrap z-score. Following the PLSC interpretation (78), the contribution of neurobehavioural loadings and corpus callosum structural characteristic loadings for a given latent component was considered robust at $\mathrm{p}<0.01$ (i.e., with a threshold of correlation coefficient above 0.4 or below -0.4 ).

- In the VPT group using corpus callosum structural characteristic measures:

PLSC was used to evaluate association between age, gestational age, general intellectual, executive and social functioning measures with corpus callosum structural characteristics in the VPT group. Neurobehavioural data refers to: age, gestational age at birth and the 6 neuropsychological measures of general intellectual, executive and social functioning. The neurobehavioural data were stored in a $65 \times 8$ matrix denoted $X$. Each row of $X$ represents one participant and the matrix's 8 columns are made up of age, gestational age at birth and the 6 neuropsychological measures. Corpus callosum structural characteristic measures were gathered in a $65 \times 33$ matrix denoted $Y$, with each row matching one participant and each column one corpus callosum structural characteristic measures. A procedure similar to the previously described PLSC conducted in fullterm control was then used in the VPT group.

- In the VPT group using W-scores of corpus callosum structural characteristic:

PLSC was used to evaluate association between age, gestational age, general intellectual, executive and social functioning measures with W-scores of corpus callosum structural characteristics in the VPT group. W-scores quantify deviation from normative neurodevelopment. Neurobehavioural data refers to: age, gestational age at birth and the 6 neuropsychological measures of general intellectual, executive and social functioning. The neurobehavioural data were stored in a $69 \times 8$ matrix denoted 
medRxiv preprint doi: https://doi.org/10.1101/2021.11.02.21265740; this version posted November 8, 2021. The copyright holder for this preprint (which was not certified by peer review) is the author/funder, who has granted medRxiv a license to display the preprint in

All rights reserved. No reuse allowed without permission.

$X$. Each row of $X$ represents one participant and the matrix's 8 columns are made up of age, gestational age at birth and the 6 neuropsychological measures. W-scores of corpus callosum structural characteristic measures were gathered in a $69 \times 33$ matrix denoted $Y$, with each row matching one participant and each column one W-scores of corpus callosum structural characteristic. A procedure similar to the previously described PLSC conducted on original corpus callosum measurements in VPT individuals was then used with W-scores.

For all PLSC, robust results are reported in terms of bootstrapping mean and standard deviations.

\section{Results}

\section{Participant characteristics}

The final sample included 65 VPT and 39 full-term participants between 6 and 14 years of age, see Table 1. Baseline characteristics were similar between VPT and full-term participants for sex and age at assessment. Socioeconomic status, as measured by the Largo score, showed group difference, with lower socio-economic status (i.e higher Largo score) in the VPT group compared to the fullterm group.

Table 1. Neonatal and demographic characteristics of the VPT and full-term participants

\begin{tabular}{|c|c|c|c|}
\cline { 2 - 4 } \multicolumn{1}{c|}{} & VPT (n=65) & $\begin{array}{c}\text { Full-term } \\
\text { (n=39) }\end{array}$ & Group comparison \\
\hline $\begin{array}{c}\text { Birth weight } \\
\text { mean (SD) in grams }\end{array}$ & $\begin{array}{c}1288.00 \\
(378.62)\end{array}$ & $\begin{array}{c}3438.72 \\
(412.05)\end{array}$ & $\mathrm{t}(95.67)=-33.89, \mathrm{p}<0.001$ \\
\hline $\begin{array}{c}\text { Gestational Age } \\
\text { mean (SD) in weeks }\end{array}$ & $29.59(1.73)$ & $39.83(1.33)$ & $\mathrm{t}(74.85)=-26.56, \mathrm{p}<0.001$ \\
\hline $\begin{array}{c}\text { Age at assessment } \\
\text { mean (SD) in months }\end{array}$ & $122.97(27.76)$ & $122.46(26.55)$ & $\mathrm{t}(82.98)=0.09, \mathrm{p}=0.93$ \\
\hline Sex, $\mathrm{n}$ & 33 females & 17 females & $X^{2}(1, N=104)=0.5, p=$ \\
\hline $\begin{array}{c}\text { Socio-economic risk } \\
\text { mean (SD) }\end{array}$ & $4.44(2.55)$ & $2.89(1.29)$ & $\mathrm{t}(99.01)=4.05, \mathrm{p}<0.001$ \\
\hline
\end{tabular}

Note: Socio-economic status of the parents was estimated using the Largo scale, a validated 12point score based on maternal education and paternal occupation (79). Higher largo scores reflect 
medRxiv preprint doi: https://doi.org/10.1101/2021.11.02.21265740; this version posted November 8, 2021. The copyright holder for this preprint (which was not certified by peer review) is the author/funder, who has granted medRxiv a license to display the preprint in All rights reserved. No reuse allowed without permission.

lower socio-economic status. Independent-sample t-test or Chi-square as appropriate were used to compare the VPT and the full-term groups.

Corpus callosum structural characteristics and association with age, gestational age and neuropsychological functioning in full-term and VPT children and adolescents

PLSC analysis applied on neurobehavioural measures (i.e., age, gestational age at birth and 6 neuropsychological measures of general intellectual, executive and social functioning) and corpus callosum structural characteristics measures identified:

a) in the full-term control group: one statistically significant latent component, latent component 1 ( $p$ $=0.001)$;

b) in the VPT group: one statistically significant latent component, latent component 1 ( $p=0.001)$.

For the two groups, a comparable latent component 1 revealed an increased in age and in general intellectual functioning associated with a general increased in mean FA and decreased in mean ODI for all segments of the corpus callosum, as well as an increased in mean NDI in the rostrum. Moreover, in the VPT group only, latent component 1 also show a significant decrease in reaction time of the congruent condition of the flanker task, i.e., increase in processing speed; and increased at the number-letter sequencing, i.e., increase in working memory, associated with the same pattern of increase FA and decrease ODI for all segments of the corpus callosum, along with an increase in volume for all portions of the corpus callosum, see Figure 3. Bootstrapping mean and standard deviations are reported in Supplementary Table S3. 
medRxiv preprint doi: https://doi.org/10.1101/2021.11.02.21265740; this version posted November 8, 2021. The copyright holder for this preprint (which was not certified by peer review) is the author/funder, who has granted medRxiv a license to display the preprint in

All rights reserved. No reuse allowed without permission.

\section{PLSC using corpus callosum structural characteristics measures}

\section{Full-term}

1.a. Neurobehavioural loadings

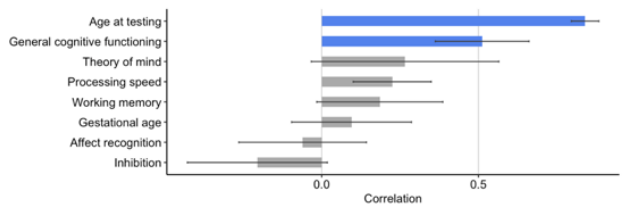

1.b. Robust corpus callosum structural characteristics loadings

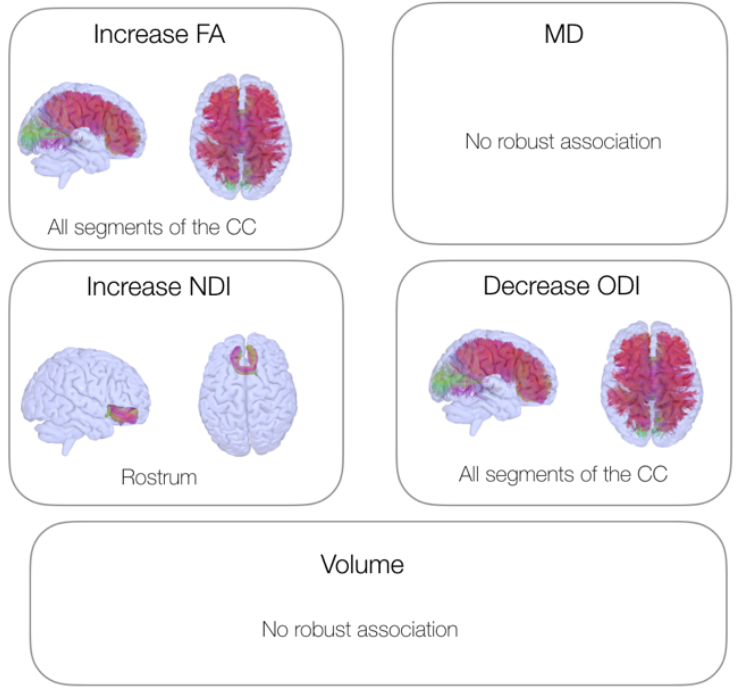

2. VPT

2.a. Neurobehavioural loadings

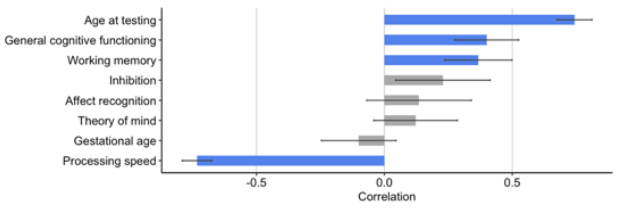

2.b. Robust corpus callosum structural characteristics loadings

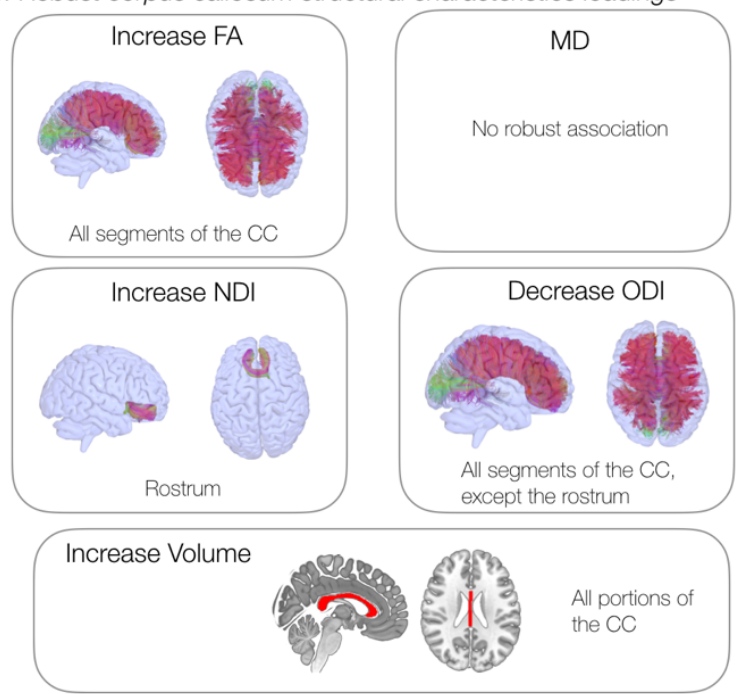

Figure 3. Associations between neurobehavioural and corpus callosum structural characteristics measures (i.e., volume, FA, MD, NDI, ODI) based on the PLSC analysis.

1) In the full-term control group: 1.a) Neurobehavioural loadings: the diverging graph show mean correlations averaged across bootstrap samples and their bootstrap-estimated standard deviations (x-axis) for each neurobehavioural measure (y-axis); robust loadings are represented in blue. 1.b) Robust corpus callosum structural characteristics loadings for each measure and concerned corpus callosum segment or portion. 2) In the VPT group: 2.a) Neurobehavioural loadings: the diverging graph show mean correlations averaged across bootstrap samples and their bootstrap-estimated standard deviations (x-axis) for each neurobehavioural measure (y-axis); robust loadings are represented in blue. 2.b) Robust corpus callosum structural characteristics loadings for each measure and concerned corpus callosum segment or portion.

W-score of corpus callosum structural characteristics and association with age, gestational age and neuropsychological functioning in VPT

PLSC analysis applied on neurobehavioural measures (i.e., age, gestational age at birth and the 6 neuropsychological measures of general intellectual, executive and social functioning) and W-scores 
medRxiv preprint doi: https://doi.org/10.1101/2021.11.02.21265740; this version posted November 8, 2021. The copyright holder for this preprint (which was not certified by peer review) is the author/funder, who has granted medRxiv a license to display the preprint in All rights reserved. No reuse allowed without permission.

of corpus callosum structural characteristics in the VPT group identified one statistically significant latent component: latent component 1 ( $p=0.001)$, see Figure 4. In the VPT group, latent component 1 revealed that decreased general intellectual functioning and working memory, i.e., measured by number-letter sequencing, were associated with deviations from normative corpus callosum structural characteristics, including reduced mean FA and increased mean ODI on all segments of the corpus callosum as well as reduced MD, increased NDI and increased volume on the midposterior and posterior portion. Interestingly, loadings of W-scores of corpus callosum structural characteristics also show robust association with age and gestational age. Increased age at testing and decreased gestational age were overall associated with deviations from normative corpus callosum structural characteristics for mean FA and MD, (i.e., below normative expectation) and mean ODI, NDI and volumes (i.e., above normative expectation). These results reflect that the older and the "more preterm" participants are, the more they show a deviation from typical development of callosal structural characteristics. Bootstrapping mean and standard deviations are reported in Supplementary Table S4. 


\section{PLSC using W-scores of corpus callosum structural characteristics in VPT children and adolescents}

a. Neurobehavioural loadings

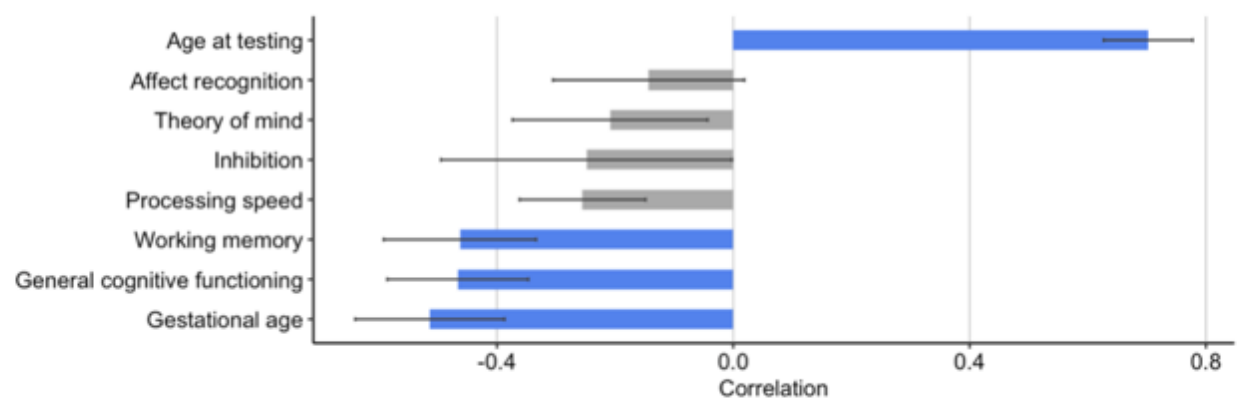

b. Robust corpus callosum structural characteristics loadings
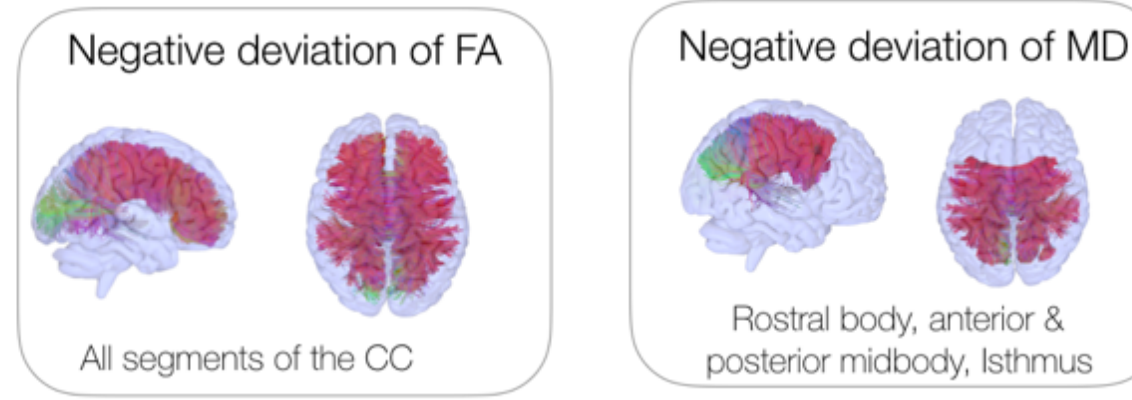

Rostral body, anterior \& posterior midbody, Isthmus

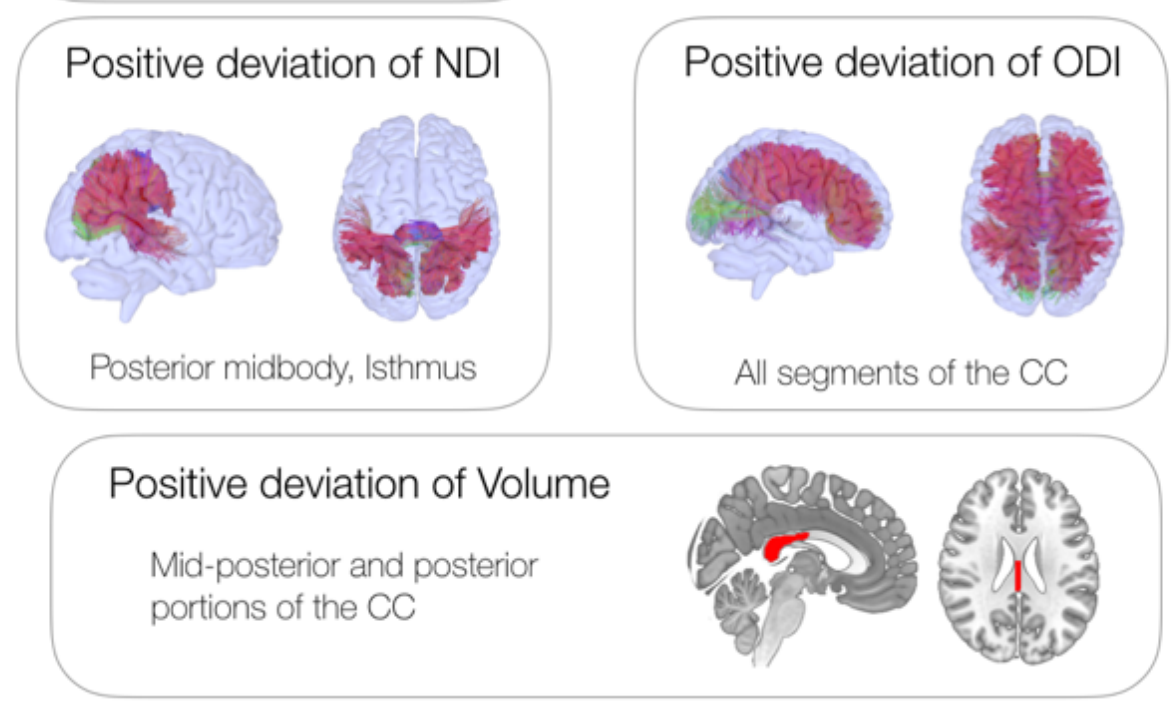

Figure 4. Associations between neurobehavioural measures and W-scores of corpus callosum structural characteristics measures (i.e., volume, FA, MD, NDI, ODI) based on the PLSC analysis. a) Neurobehavioural loadings: the diverging graph show mean correlations averaged across bootstrap samples and their bootstrap-estimated standard deviations (x-axis) for each neurobehavioural measure (y-axis); robust loadings are represented in blue. 1.b) Robust W-scores of corpus callosum structural characteristics loadings and concerned corpus callosum segment or portion. 
medRxiv preprint doi: https://doi.org/10.1101/2021.11.02.21265740; this version posted November 8, 2021. The copyright holder for this preprint (which was not certified by peer review) is the author/funder, who has granted medRxiv a license to display the preprint in

All rights reserved. No reuse allowed without permission.

\section{Discussion}

The present study aims to unravel corpus callosum structural characteristics across development in VPT children and adolescents aged 6 to 15 years, as well their associations with general intellectual, executive and social functioning.

Using multi-modal structural measures of the corpus callosum, i.e., volume, tensor and noddi measures, the VPT and full-term control group show overall comparable pattern of association between age and neuropsychological functioning with corpus callosum structural characteristics. In both the VPT and full-term control group, age and general intellectual functioning were positively associated with FA and negatively associated with ODI in most segment of the corpus callosum. During typical development, the increase in FA in callosal regions and callosal white-matter tracts is well documented within the age-range of 6 to 15 years of age $(57,80)$. For both groups, this agerelated increase in FA was dominated by decreasing ODI in most callosal segment which points to increasing coherence of axons. The rostrum also showed a specific increase in NDI reflecting increase in fibre diameter and myelination $(57,81)$. This coupling of increase FA and reduced ODI in most callosal tracts was also associated with general intellectual functioning in both the VPT and the full-term control groups. These findings, reflecting the important role of the corpus callosum in general intellectual development, are in line with previous studies conducted in typically developing and VPT populations $(37,39,82)$. Specific to the VPT group, age as well as general intellectual and executive functioning, i.e., working memory and processing speed, were positively associated with the volume of all portions of the corpus callosum. These findings suggest a late or accelerated volumetric growth of the corpus callosum in VPT school-aged children as proposed in previous studies, that reconciles with delayed maturation at earlier stages of development (83).

Overall, in light of advanced diffusion measures of the corpus callosum, the VPT and full-term control group showed comparable trends of callosal maturation reflecting increasing axonal coherence, as well as consistent association with general intellectual functioning. Using volumetric measurement, VPT children and adolescents also show a specific increase in callosal volumes with age. In the VPT group, the pattern of increase volume and FA and decrease ODI was not only associated with general intellectual functioning but also with executive functioning.

Despite apparent effective growth and maturation of callosal regions and white matter tracts in the VPT group, age-related normative modelling of corpus callosum structural characteristics unravel important patterns of deviations from normative neurodevelopment. In the VPT group, age was 
medRxiv preprint doi: https://doi.org/10.1101/2021.11.02.21265740; this version posted November 8, 2021. The copyright holder for this preprint (which was not certified by peer review) is the author/funder, who has granted medRxiv a license to display the preprint in

All rights reserved. No reuse allowed without permission.

associated with a pattern of negative deviation from normative development of FA and positive deviation of ODI on all callosal segments. This reflects that despite an apparent white-matter callosal maturation similar to the full-term with respect to increasing FA and decreasing ODI over age, callosal maturation in the VPT group is significantly slower and the deviation from normative callosal development increases as VPT children grow older. Greater prematurity was also associated with this atypical pattern of negative deviation of FA and positive deviation of ODI; meaning that the more VPT children are born prematurely the more they deviate from normative callosal development. These findings are consistent with previous studies showing a significant impact of the level of prematurity onto callosal structural development $(35,36)$. Moreover, atypical profile of callosal structural characteristics in VPT children were also associated with reduced general intellectual and working memory functioning. In addition to atypical developmental trajectories of FA and ODI measures for all callosal segment in VPT, posterior portions of the corpus callosum seems particularly altered in this population. Indeed, posterior portions showed positive deviation of NDI and volumes as well as negative deviation of MD associated with age. As mentioned above, these results could be interpreted as increases or accelerated maturation processes linked to increase fibre diameter and myelination (83). Nevertheless, these neuroplastic processes that are probably in place to compensate for delayed maturation at earlier age are not yet sufficient as they were associated with poorer general intellectual and working memory functioning.

A limitation of the current study is the use of cross-sectional data to model callosal development. Individual variability in neurodevelopment not only occurs at inter-individual, but also intra-individual level (84). Therefore, characterising factors that explain intra-individual variability during neurodevelopment is of high interest. In this context, future work should consider using longitudinal data and follow-up time points to better understand intra-individual variability.

\section{Conclusions}

In conclusion, despite apparent growth and maturation of callosal regions and white-matter tracts in school-aged VPT close to full-term controls, age-related normative modelling of volumetric, tensor and NODDI diffusion measures unravel atypical pattern of callosal development. Callosal maturation appear to deviate from normative expectation with reduced maturation over time but also with a typical developmental trajectory. Atypical developmental trajectory of callosal maturation was associated with poorer general intellectual and working memory functioning as well as with greater prematurity. The present study also illustrates how normative age modelling approach allows to shed 
medRxiv preprint doi: https://doi.org/10.1101/2021.11.02.21265740; this version posted November $8,2021$. The copyright holder for this preprint (which was not certified by peer review) is the author/funder, who has granted medRxiv a license to display the preprint in

All rights reserved. No reuse allowed without permission.

new insight into neurodevelopmental trajectory in the VPT population and its association with functional outcomes.

\section{Acknowledgements}

We thank and acknowledge all participating young adolescents and families who made this research possible. We also thank the Fondation Campus Biotech Geneva (FCBG), a foundation of the Swiss Federal Institute of Technology Lausanne (EPFL), the University of Geneva (UniGe), and the University

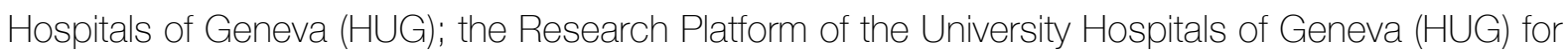
their practical help.

Funding: This work was supported by the Swiss National Science Foundation, No. 324730_163084 [PI: P.S. Hüppi].

\section{References}

1. Edwards TJ, Sherr EH, Barkovich AJ, Richards LJ (2014): Clinical, genetic and imaging findings identify new causes for corpus callosum development syndromes. Brain. 137:1579-1613.

2. Gazzaniga MS (2000): Cerebral specialization and interhemispheric communication: does the corpus callosum enable the human condition? Brain. 123 ( Pt 7):1293-1326.

3. Hofer S, Frahm J (2006): Topography of the human corpus callosum revisited-comprehensive fiber tractography using diffusion tensor magnetic resonance imaging. NeuroImage. 32:989-994.

4. Hofer S, Merboldt KD, Tammer R, Frahm J (2008): Rhesus monkey and humans share a similar topography of the corpus callosum as revealed by diffusion tensor MRI in vivo. Cerebral Cortex. 18:1079-1084.

5. Hutchinson AD, Mathias JL, Jacobson BL, Ruzic L, Bond AN, Banich MT (2009): Relationship between intelligence and the size and composition of the corpus callosum. Experimental brain research Experimentelle Hirnforschung Experimentation cerebrale. 192:455-464.

6. Siffredi V, Anderson VA, McIlroy A, Wood A, Leventer RJ, Spencer-Smith MJJotINS (2018): A Neuropsychological Profile for Agenesis of the Corpus Callosum?: Cognitive, Academic, Executive, Social, and Behavioral Functioning in School-Age Children.1-11.

7. Luders E, Narr KL, Bilder RM, Thompson PM, Szeszko PR, Hamilton L, et al. (2007): Positive correlations between corpus callosum thickness and intelligence. NeuroImage. 37:1457-1464. 
medRxiv preprint doi: https://doi.org/10.1101/2021.11.02.21265740; this version posted November 8,2021 . The copyright holder for this preprint (which was not certified by peer review) is the author/funder, who has granted medRxiv a license to display the preprint in

8. Fryer SL, Frank LR, Spadoni AD, Theilmann RJ, Nagel BJ, Schweinsburg AD, et al. (2008): Microstructural integrity of the corpus callosum linked with neuropsychological performance in adolescents. Brain Cogn. 67:225-233.

9. Lyoo IK, Noam GG, Lee CK, Lee HK, Kennedy BP, Renshaw PF (1996): The corpus callosum and lateral ventricles in children with attention-deficit hyperactivity disorder: a brain magnetic resonance imaging study. Biol Psychiatry. 40:1060-1063.

10. Brown WS, Panos A, Paul LK (2020): Attention, impulsivity, and vigilance in agenesis of the corpus callosum. Neuropsychology.

11. Hinkley LB, Marco EJ, Findlay AM, Honma S, Jeremy RJ, Strominger Z, et al. (2012): The role of corpus callosum development in functional connectivity and cognitive processing. PloS one. 7:e39804.

12. Kok R, Lucassen N, Bakermans-Kranenburg MJ, Van Ijzendoorn MH, Ghassabian A, Roza SJ, et al. (2014): Parenting, corpus callosum, and executive function in preschool children. Child neuropsychology : a journal on normal and abnormal development in childhood and adolescence. 20:583-606.

13. Siffredi V, Spencer-Smith MM, Barrouillet P, Vaessen MJ, Leventer RJ, Anderson V, et al. (2017): Neural correlates of working memory in children and adolescents with agenesis of the corpus callosum: An fMRI study. Neuropsychologia. 106:71-82.

14. Hardan AY, Pabalan M, Gupta N, Bansal R, Melhem NM, Fedorov S, et al. (2009): Corpus callosum volume in children with autism. Psychiatry research. 174:57-61.

15. Badaruddin DH, Andrews GL, Bolte S, Schilmoeller KJ, Schilmoeller G, Paul LK, et al. (2007): Social and behavioral problems of children with agenesis of the corpus callosum. Child psychiatry and human development. 38:287-302.

16. Barnea-Goraly N, Kwon H, Menon V, Eliez S, Lotspeich L, Reiss AL (2004): White matter structure in autism: preliminary evidence from diffusion tensor imaging. Biol Psychiatry. 55:323-326.

17. Bridgman MW, Brown WS, Spezio ML, Leonard MK, Adolphs R, Paul LK (2014): Facial emotion recognition in agenesis of the corpus callosum. J Neurodev Disord. 6:32.

18. Paul LK, Brown WS, Adolphs R, Tyszka JM, Richards LJ, Mukherjee P, et al. (2007): Agenesis of the corpus callosum: genetic, developmental and functional aspects of connectivity. Nature Reviews Neuroscience. 8:287-299.

19. Lindwall C, Fothergill T, Richards LJ (2007): Commissure formation in the mammalian forebrain. Current opinion in neurobiology. 17:3-14.

20. Rakic P, Yakovlev PI (1968): Development of the corpus callosum and cavum septi in man. The Journal of comparative neurology. 132:45-72.

21. Giedd JN, Rumsey JM, Castallanos FX, Rajapakse JC, Kaysen D, Vaituzis AC, et al. (1996): A quantitative MRI study of the corpus callosum in children and adolescents. Brain Research: Developmental Brain Research. 91:274-280.

22. Pujol J, Vendrell P, Junque C, Marti-Vilalta JL, Capdevila A (1993): When does human brain development end? Evidence of corpus callosum growth up to adulthood. Annals of neurology. 34:71-75.

23. Rauch RA, Jinkins JR (1994): Magnetic resonance imaging of corpus callosum dysgenesis. In: Lassonde M, Jeeves MA, editors. Callosal Agenesis: A Natural Split Brain? . New York: Plenum, pp 83-95.

24. Malinger G, Zakut H (1993): The corpus callosum: normal fetal development as shown by transvaginal sonography. American journal of roentgenology. 161:1041-1043.

25. Innocenti GM, Price DJ (2005): Exuberance in the development of cortical networks. Nature reviews Neuroscience. 6:955-965. 
medRxiv preprint doi: https://doi.org/10.1101/2021.11.02.21265740; this version posted November 8,2021 . The copyright holder for this preprint (which was not certified by peer review) is the author/funder, who has granted medRxiv a license to display the preprint in

26. Hüppi PS, Maier SE, Peled S, Zientara GP, Barnes PD, Jolesz FA, et al. (1998): Microstructural development of human newborn cerebral white matter assessed in vivo by diffusion tensor magnetic resonance imaging. Pediatric research. 44:584-590.

27. Hasegawa T, Yamada K, Morimoto M, Morioka S, Tozawa T, Isoda K, et al. (2011): Development of corpus callosum in preterm infants is affected by the prematurity: in vivo assessment of diffusion tensor imaging at term-equivalent age. Pediatric research 69:249-254. 28. Teli R, Hay M, Hershey A, Kumar M, Yin H, Parikh NA (2018): Postnatal microstructural developmental trajectory of corpus callosum subregions and relationship to clinical factors in very preterm infants. Scientific reports. 8:1-12.

29. Thompson DK, Inder TE, Faggian N, Johnston L, Warfield SK, Anderson PJ, et al. (2011): Characterization of the corpus callosum in very preterm and full-term infants utilizing MRI. NeuroImage. 55:479-490.

30. Huang H-C, Chou H-C, Tsao P-N, Chen C-Y (2020): Linear growth of corpus callosum and cerebellar vermis in very-low-birth-weight preterm infants. Journal of the Formosan Medical Association. 119:1292-1298.

31. de Bruïne FT, van Wezel-Meijler G, Leijser LM, van den Berg-Huysmans AA, van Steenis A, van Buchem MA, et al. (2011): Tractography of developing white matter of the internal capsule and corpus callosum in very preterm infants. European radiology. 21:538-547. 32. van Pul C, van Kooij BJ, de Vries LS, Benders MJ, Vilanova A, Groenendaal F (2012): Quantitative fiber tracking in the corpus callosum and internal capsule reveals microstructural abnormalities in preterm infants at term-equivalent age. American journal of neuroradiology. 33:678-684.

33. Rademaker K, Lam J, Van Haastert I, Uiterwaal C, Lieftink A, Groenendaal F, et al. (2004): Larger corpus callosum size with better motor performance in prematurely born children. Seminars in perinatology: Elsevier, pp 279-287.

34. Caldú X, Narberhaus A, Junqué C, Giménez M, Vendrell P, Bargalló N, et al. (2006): Corpus callosum size and neuropsychologic impairment in adolescents who were born preterm. Journal of child neurology. 21:406-410.

35. Narberhaus A, Segarra D, Caldú X, Giménez M, Junqué C, Pueyo R, et al. (2007): Gestational age at preterm birth in relation to corpus callosum and general cognitive outcome in adolescents. Journal of child neurology. 22:761-765.

36. Narberhaus A, Segarra D, Caldú X, Giménez M, Pueyo R, Botet F, et al. (2008): Corpus callosum and prefrontal functions in adolescents with history of very preterm birth. Neuropsychologia. 46:111-116.

37. Nosarti C, Rushe TM, Woodruff PW, Stewart AL, Rifkin L, Murray RM (2004): Corpus callosum size and very preterm birth: relationship to neuropsychological outcome. Brain. 127:2080-2089.

38. Nosarti C, Nam KW, Walshe M, Murray RM, Cuddy M, Rifkin L, et al. (2014): Preterm birth and structural brain alterations in early adulthood. NeuroImage: Clinical. 6:180-191.

39. Allin M, Nosarti C, Narberhaus A, Walshe M, Frearson S, Kalpakidou A, et al. (2007): Growth of the corpus callosum in adolescents born preterm. Archives of pediatrics adolescent medicine. 161:1183-1189.

40. Pierpaoli C, Jezzard P, Basser PJ, Barnett A, Di Chiro G (1996): Diffusion tensor MR imaging of the human brain. Radiology. 201:637-648.

41. Jo HM, Cho HK, Jang SH, Yeo SS, Lee E, Kim HS, et al. (2012): A comparison of microstructural maturational changes of the corpus callosum in preterm and full-term children: a diffusion tensor imaging study. Neuroradiology. 54:997-1005.

42. Thompson DK, Lee KJ, van Bijnen L, Leemans A, Pascoe L, Scratch SE, et al. (2015): Accelerated corpus callosum development in prematurity predicts improved outcome. Hum Brain Mapp. 36:3733-3748. 
medRxiv preprint doi: https://doi.org/10.1101/2021.11.02.21265740; this version posted November 8,2021 . The copyright holder for this preprint (which was not certified by peer review) is the author/funder, who has granted medRxiv a license to display the preprint in

43. Nagy Z, Westerberg H, Skare S, Andersson JL, Lilja A, Flodmark O, et al. (2003): Preterm children have disturbances of white matter at 11 years of age as shown by diffusion tensor imaging. Pediatric Research. 54:672-679.

44. Kontis D, Catani M, Cuddy M, Walshe M, Nosarti C, Jones D, et al. (2009): Diffusion tensor MRI of the corpus callosum and cognitive function in adults born preterm. Neuroreport. 20:424-428.

45. Jones DK, Knösche TR, Turner R (2013): White matter integrity, fiber count, and other fallacies: the do's and don'ts of diffusion MRI. NeuroImage. 73:239-254.

46. Nemanich ST, Mueller BA, Gillick BT (2019): Neurite orientation dispersion and density imaging quantifies corticospinal tract microstructural organization in children with unilateral cerebral palsy. Hum Brain Mapp. 40:4888-4900.

47. Zhang H, Schneider T, Wheeler-Kingshott CA, Alexander DC (2012): NODDI: practical in vivo neurite orientation dispersion and density imaging of the human brain. NeuroImage. 61:1000-1016.

48. Marquand AF, Rezek I, Buitelaar J, Beckmann CF (2016): Understanding heterogeneity in clinical cohorts using normative models: beyond case-control studies. Biological psychiatry. 80:552-561.

49. Lefebvre A, Delorme R, Delanoë C, Amsellem F, Beggiato A, Germanaud D, et al. (2018): Alpha waves as a neuromarker of autism spectrum disorder: the challenge of reproducibility and heterogeneity. Frontiers in neuroscience. 12:662.

50. Bethlehem RA, Seidlitz J, Romero-Garcia R, Trakoshis S, Dumas G, Lombardo MV (2020): A normative modelling approach reveals age-atypical cortical thickness in a subgroup of males with autism spectrum disorder. Communications biology. 3:1-10.

51. Siffredi V, Liverani MC, Magnus-Smith M, Meskaldji D, Stuckelberger-Grobety F, Freitas L, et al. (2021): Improving executive, behavioural and socio-emotional competences in very preterm young adolescents through a mindfulness-based intervention: study protocol and feasibility. MedRxiv: https://wwwmedrxivorg/content/101101/2021011921250087v1.

52. Kaufman AS, Kaufman NL (2013): Kaufman assessment battery for children. Encyclopedia of Special Education: A Reference for the Education of Children, Adolescents, Adults with Disabilities

Other Exceptional Individuals.

53. Wechsler D (2003): Manual for the Wechsler Intelligence Scale for Children-IV. New York: Psychological Corporation.

54. Anderson P (2002): Assessment and development of executive function (EF) during childhood. Child Neuropsychol. 8:71-82.

55. Christ SE, Kester LE, Bodner KE, Miles JH (2011): Evidence for selective inhibitory impairment in individuals with autism spectrum disorder. Neuropsychology. 25:690-701.

56. Korkman M, Kirk U, Kemp S (2007): A developmental neuropsychological assessment 2nd Edition : NEPSY-II. San Antonio, Texas: Pearson.

57. Tamnes CK, Roalf DR, Goddings A-L, Lebel C (2018): Diffusion MRI of white matter microstructure development in childhood and adolescence: Methods, challenges and progress. Developmental cognitive neuroscience. 33:161-175.

58. de Bie HM, Boersma M, Wattjes MP, Adriaanse S, Vermeulen RJ, Oostrom KJ, et al. (2010): Preparing children with a mock scanner training protocol results in high quality structural and functional MRI scans. 169:1079-1085.

59. Fischl B, Salat DH, Busa E, Albert M, Dieterich M, Haselgrove C, et al. (2002): Whole brain segmentation: automated labeling of neuroanatomical structures in the human brain. Neuron. 33:341-355. 
medRxiv preprint doi: https://doi.org/10.1101/2021.11.02.21265740; this version posted November 8,2021 . The copyright holder for this preprint (which was not certified by peer review) is the author/funder, who has granted medRxiv a license to display the preprint in

60. Tournier J-D, Smith R, Raffelt D, Tabbara R, Dhollander T, Pietsch M, et al. (2019): MRtrix3: A fast, flexible and open software framework for medical image processing and visualisation. 202:116137.

61. Veraart J, Fieremans E, Novikov DSJMrim (2016): Diffusion MRI noise mapping using random matrix theory. 76:1582-1593.

62. Veraart J, Novikov DS, Christiaens D, Ades-Aron B, Sijbers J, Fieremans EJN (2016): Denoising of diffusion MRI using random matrix theory. 142:394-406.

63. Cordero-Grande L, Christiaens D, Hutter J, Price AN, Hajnal JVJN (2019): Complex diffusion-weighted image estimation via matrix recovery under general noise models. 200:391404.

64. Kellner E, Dhital B, Kiselev VG, Reisert MJMrim (2016): Gibbs-ringing artifact removal based on local subvoxel-shifts. 76:1574-1581.

65. Jenkinson M, Beckmann CF, Behrens TE, Woolrich MW, Smith SMJN (2012): Fsl. 62:782-790.

66. Smith SMJHbm (2002): Fast robust automated brain extraction. 17:143-155.

67. Pines AR, Cieslak M, Larsen B, Baum GL, Cook PA, Adebimpe A, et al. (2020): Leveraging multi-shell diffusion for studies of brain development in youth and young adulthood. Developmental Cognitive Neuroscience. 43:100788.

68. Jeurissen B, Tournier J-D, Dhollander T, Connelly A, Sijbers JJN (2014): Multi-tissue constrained spherical deconvolution for improved analysis of multi-shell diffusion MRI data. 103:411-426.

69. Wasserthal J, Neher P, Maier-Hein KHJN (2018): TractSeg-Fast and accurate white matter tract segmentation. 183:239-253.

70. Chandio B, Harezlak J, Garyfallidis E (2019): Bundle Analytics: a computational and statistical analysis framework for tractometric studies. Organization for Human Brain Mapping.

71. Team RC (2019): R: A language and environment for statistical computing. In: Computing RFfS, editor. Vienna, Austria, pp https://www.r-project.org/.

72. Team R (2020): RStudio: Integrated Development for R. In: RStudio I, editor. Boston, MA, pp http://www.rstudio.com/.

73. Brent RP (1971): An algorithm with guaranteed convergence for finding a zero of a function. The Computer Journal. 14:422-425.

74. McIntosh AR, Lobaugh NJJN (2004): Partial least squares analysis of neuroimaging data: applications and advances. 23:S250-S263.

75. Kebets V, Holmes AJ, Orban C, Tang S, Li J, Sun N, et al. (2019): SomatosensoryMotor Dysconnectivity Spans Multiple Transdiagnostic Dimensions of Psychopathology. Biol Psychiat. 0.

76. Zoller D, Sandini C, Karahanoglu FI, Padula MC, Schaer M, Eliez S, et al. (2019): Large-Scale Brain Network Dynamics Provide a Measure of Psychosis and Anxiety in 22q11.2 Deletion Syndrome. Biological Psychiatry: Cognitive Neuroscience and Neuroimaging. 4:881892

77. Sherry A, Henson RK (2005): Conducting and interpreting canonical correlation analysis in personality research: A user-friendly primer. Journal of personality assessment. $84: 37-48$.

78. Krishnan A, Williams LJ, McIntosh AR, Abdi H (2011): Partial Least Squares (PLS) methods for neuroimaging: a tutorial and review. NeuroImage. 56:455-475.

79. Largo RH, Pfister D, Molinari L, Kundu S, Lipp A, Duc G (1989): Significance of prenatal, perinatal and postnatal factors in the development of AGA preterm infants at five to seven years. Dev Med Child Neurol. 31:440-456. 
medRxiv preprint doi: https://doi.org/10.1101/2021.11.02.21265740; this version posted November $8,2021$. The copyright holder for this preprint (which was not certified by peer review) is the author/funder, who has granted medRxiv a license to display the preprint in

All rights reserved. No reuse allowed without permission.

80. Westlye LT, Walhovd KB, Dale AM, Bjørnerud A, Due-Tønnessen P, Engvig A, et al. (2010): Life-span changes of the human brain white matter: diffusion tensor imaging (DTI) and volumetry. Cerebral cortex. 20:2055-2068.

81. Mah A, Geeraert B, Lebel C (2017): Detailing neuroanatomical development in late childhood and early adolescence using NODDI. PloS one. 12:e0182340.

82. Luders E, Narr KL, Bilder RM, Thompson PM, Szeszko PR, Hamilton L, et al. (2007): Positive correlations between corpus callosum thickness and intelligence. NeuroImage. 37:1457-1464.

83. Karolis VR, Froudist-Walsh S, Kroll J, Brittain PJ, Tseng C-EJ, Nam K-W, et al. (2017): Volumetric grey matter alterations in adolescents and adults born very preterm suggest accelerated brain maturation. NeuroImage. 163:379-389.

84. Foulkes L, Blakemore S-J (2018): Studying individual differences in human adolescent brain development. Nature neuroscience. 21:315-323. 